\title{
The Dark Side of Social Desire: Violence as Metaphor, Fantasy and Satire in Argentina, 1969-1975
}

\author{
SEBASTIÁN CARASSAI*
}

Abstract. The I970s was the most violent decade of the entire twentieth century for Argentina. Its first half was characterised by the rise of political radicalisation, and its second by the reign of state repression. Studies devoted to investigating the issue of violence in the r 970 s have concentrated fundamentally on the protagonists. By contrast, this article offers an analysis of the symbolic terrain, shifting focus from the conscious to the unconscious plane, from the real to the imaginary world. Dealing with visual representations of violence in popular culture, especially advertising in mass-circulation magazines, it explores how violence became naturalised during the first half of the I970s. In so doing it adds an additional layer to our understanding of the social mood that preceded the military coup of March 1976.

Keywords: Argentina, I970s, political violence, representations of violence, guerrilla and state terrorism

If we define the culture of a society by the circulation of symbols which occurs there, our culture appears as homogeneous and united as that of some little ethnic society.

Roland Barthes ${ }^{\mathrm{I}}$

With the fall of Juan Domingo Perón in 1955, Argentina entered an unstable institutional cycle. From that point onwards, all the attempts made by military and civilian governments to modernise the country while either ignoring or taming Peronism invariably failed. In I 969, workers and students rose up in Corrientes, Rosario, Tucumán and above all Córdoba, forcing the authorities

Sebastián Carassai is a research associate at the National Scientific and Technical Research Council (CONICET) in Buenos Aires. He is a member of the Centre of Intellectual History at the National University of Quilmes, and an assistant professor in the Department of Sociology at the University of Buenos Aires. Email: scarassai@conicet.gov.ar.

* I would to thank Kevin Coleman at the University of Toronto and the attendees of my talk at the Center for the Study of History and Memory at Indiana University, directed by John Bodnar and Daniel James, as well as the anonymous JLAS reviewers for their helpful comments and suggestions.

I Roland Barthes (trans. Richard Howard), The Rustle of Language (Berkeley and Los Angeles, CA: University of California Press, i989), p. i I I. 
to reconsider their course. The military government of the 'Argentine Revolution' (1966-73) gave up on the proscription of Peronism, and three years later called for free elections. In March 1973 , nearly half of the electorate voted to elect the Peronist Héctor Cámpora and his running mate Vicente Solano Lima. They resigned in July of the same year, and a new round of elections in September enabled Perón himself to reach the presidency, accompanied by his wife as vice-president.

However, the arrival of democracy did not alter the rising trend in the cycle of violence that began in the late 1960 . The state reacted to the social revolts and guerrilla activity by ramping up its repressive functions, including protecting paramilitary groups that dramatically increased violence. The Ezeiza Massacre, which occurred in June 1973 when Perón returned to the country for good, turned out to be prophetic. The internal struggles between the Peronist Left and Right would become the crucial variable in the coming years. The Alianza Anticomunista Argentina (Argentine Anti-Communist Alliance, known as the Triple A), linked to the Peronist Right and protected by the government, showed that the state was willing to go beyond legality in order to repress the Left. Perón's death on I July 1974 accelerated the debacle. In March 1976, a military coup put an end to the government of Perón's widow Isabel Martínez; this new administration, the self-styled Proceso de Reorganización Nacional (National Reorganisation Process, known as 'el Proceso'), would shortly exercise a monopoly not only over violence but also over death. Studies devoted to analysing the issue of violence in the I 970 s have concentrated fundamentally on the protagonists. However, this article offers an exploration in the symbolic terrain, taking the analysis from the real to the imaginary world and adding a new dimension to recent works that have opened up this line of enquiry. ${ }^{2}$ Looking at visual representations of violence in popular culture, this article explores how violence became naturalised during the first half of the I970s, adding a further element to our understanding of the social mood that held sway at the moment when the state began to monopolise violence and terror in March $1976.3^{3}$

2 See, for example, Beatriz Sarlo, La pasión y la excepción (Buenos Aires: Siglo XXI, 2003); and Hugo Vezzetti, Sobre la violencia revolucionaria: memorias y olvidos (Buenos Aires: Siglo XXI, 2009). See also the pioneering work of Emilio de Ípola and Liliana de Riz, 'Un juego de "cartas políticas": intelectuales y discurso autoritario en la Argentina actual', in Daniel Camacho et al., América Latina: ideología y cultura (San José de Costa Rica: FLACSO, I 982 ), pp. 83-i I 2 .

${ }^{3}$ For an analysis of official policies regarding media in the 1970s, see Héctor Schmucler and Margarita Zires, 'El papel ideológico de los medios de comunicación', Comunicación y Cultura, 5 (1978), pp. I I9-78; and Heriberto Muraro, 'La comunicación masiva durante la dictadura militar y la transición democrática en la Argentina, 1973-1986', in Oscar Landi (ed.), Medios, transformación cultural y politica (Buenos Aires: Legasa, 1987), pp. 13-57. 
A survey conducted in $1971-2$ reached paradoxical conclusions. On the one hand, a majority of the population rejected the actions of the guerrilla groups and the current military government. On the other hand, a question that asked how the problems that plagued society could be solved received drastic answers. In the four districts where the poll was conducted, large proportions of people interviewed selected the option advocating that the country should 'start from scratch and change everything from the root'. ${ }^{4}$ Interpreting these results, the survey report concluded that Argentine society had a 'basic predisposition to be sympathetic to any attempt to introduce fundamental changes in the existing [social] order'.s Although the majority of the population supported neither the guerrilla organisations nor the 'Argentine Revolution' propounded by the military government, they nonetheless shared a rejection of gradual transformations and a belief in the need for radical, total and immediate change.

In this article I propose that, beyond the concrete actors who exercised violence on the material plane, the I 970 s played out against a background of violence that was subconsciously shared by wide sectors of society and evidenced in the unusually high number of images and metaphors of violence deployed by the cultural industry in those years. The material considered comes from magazines intended for mass consumption, both those focusing on political analysis and those devoted to sports, fashion or general interest, from some of the main daily newspapers and, to a lesser degree, from television and cinema. The very nature of these cultural products enhances their meaning and resonance. The great majority combined brief texts (slogans, phrases or headlines) with striking or shocking images. Although only a selection are reproduced here, one should not underestimate their power, an impact inherent to the field of visual representations. ${ }^{6}$

Edgar Morin wrote that the cultural industry constituted a second phase of industrialisation, one that was dedicated to producing not objects but rather images and dreams. Among these products, those from the advertising world acquire special relevance for four reasons. First, they aspire to seduce the

${ }^{4}$ Centro de Investigaciones Motivacionales y Sociales, 'Medidas de las insatisfacciones y del apoyo que tiene el funcionamiento del sistema existente', Estudio no. ıoo, Colección José Enrique Miguens, 1958-1973, Colecciones Especiales y Archivos, Universidad de San Andrés, Argentina, 1971.

5 Another measurement of public opinion, conducted by the International Political Science Association (IPSA) in November 1972 (when the electoral process was already opened up), also showed that large groups of the population declared themselves to be in favour of drastic options. Institute IPSA, POLITICS/BUSINESS (computer file), Roper Center for Public Opinion. Research Study ARIPSA 1972-OPo39, Version 3, 1972 (Storrs, CT: Roper Center for Public Opinion Research, University of Connecticut, 2006).

${ }^{6}$ Analysts emphasise the importance of the print media market over the audiovisual market in the advertising industry of the 1970s. See 'Periodismo: la revancha de las revistas', Confirmado, 393, I5-21 May 1973, pp. 30-2. 
consumer, inducing him or her to buy what is being advertised at the same time that they are immediately consumed by those who see, read or hear them. Second, advertising by its very nature is a product that is obliged to speak the language of those it seeks to attract. Third, it was in the late 1960s that investment in advertising began playing an unprecedentedly significant role. ${ }^{7}$ Finally, towards the end of the 1960 s and with growing force in the early I970s, violence became part of the very discourse of Argentine marketing. ${ }^{8}$

Significantly, paid advertising directed toward the same target audiences in the United States (Newsweek and Life), France (Paris Match) and Germany (Der Spiegel) used neither weapons nor violent metaphors to appeal to its readers/consumers, at least between 1969 and 1975 , despite the fact that each of these publications shared a similar aesthetic to Argentine advertising. ${ }^{9}$ With regard to Argentina, the increase in representations and metaphors of violence in the symbolic space, a process that began toward the end of the 1960 , was abruptly interrupted by the military coup of 24 March 1976. Through Decree I,329/76, the Military Junta declared that on I August 1976, all licences authorising the possession and/or carrying of firearms would expire, setting a penalty of up to ten years in prison for those who carried unauthorised weapons. ${ }^{10}$ This act had its correlation in the symbolic space. News articles alluding to 'weapons stockpiles' belonging to 'subversive cells' or 'extremists' that had been decommissioned by the 'forces of the law' multiplied, and were joined by others that showed the weapons 'in their rightful place' - that is, in the hands of the military, the police or the gendarmes. Companies that used revolvers or shotguns in their advertisements, such as Cosak, Levi's and Sorpasso, stopped doing so. ${ }^{11}$ Days after the coup d'état, for example, the Musiplast company, responsible for the production of the 'Guerrillero' toy machine gun, published notes in newspapers announcing that it would stop producing the item and asking for it to be withdrawn from sale. ${ }^{12}$

7 See Anibal Ford and Jorge B. Rivera, 'Los medios masivos de comunicación en la Argentina', in Aníbal Ford, Jorge B. Rivera and Eduardo Romano, Medios de comunicación y cultura popular (Buenos Aires: Legasa, 1985). The advertising industry in Argentina was primarily divided between subsidiaries of US companies such as McCann-Erickson, J. Walter Thompson and Grant Adv., managed by Argentine professionals, and local companies such as Yuste, Eter, Pueyrredón Propaganda, Gowland, De Luca and Nexo Publicidad. See Laura Podalsky, Specular City: Transforming Culture, Consumption, and Space in Buenos Aires, 1955-1973 (Philadelphia, PA: Temple University Press, 2004), pp. 2 I 3-2 I.

${ }^{8}$ See Armando Alonso Piñeiro, Breve historia de la publicidad argentina (I80I-1974) (Buenos Aires: Alzamor, 1974).

9 The Marlboro Man in the United States perhaps represents one of the few exceptions to this rule. $\quad$ Io 'Caducaron los permisos para portar armas', La Capital, i Aug. 1976.

${ }^{1}$ See Auto Club, a magazine in which sports occupied an important place. Until 1976, Auto Club regularly included advertisements for guns and munitions, often dozens in the same issue. After the coup, the magazine reduced, modified or cancelled these types of ads in its pages.

${ }_{12}$ See the 9 April 1976 editions of Clarin and La Razón. 
Julio Pisarewcz, the owner of the toy company, publicly apologised for having launched the product. ${ }^{13}$

In this article I first analyse the increasingly abundant presence of firearms within the symbolic space of journalistic images and, crucially, paid advertising. I then examine metaphors of violence and subsequently focus on depictions of violence that were associated with sexual fantasies. I conclude by analysing the political humour of the first half of the 1970s, in which representations of violence became relevant.

\section{Guns}

During the late I960s and increasingly during the early I970s, guns began to occupy an atypical space within the advertising world. They sometimes accentuated manliness, security, ambition or the readiness to embrace drastic solutions. In other cases, they connoted values such as friendship or the desire to lead an exciting or adventurous lifestyle. Finally, both in fashion and in other consumer goods directed toward women, weapons served as metaphors of sensuality and seduction.

Before analysing the universe of paid advertising, it is worth reflecting on the way in which several Argentine celebrities, from athletes to fashion models, sought to promote themselves. Carlos Monzón, the 1970 world boxing champion and an indisputable idol of Argentine society, posed with guns in various press articles. ${ }^{14}$ In 1972, Gente, the magazine with the largest readership among the general-interest titles, photographed him gazing toward the horizon of a country landscape, alone, hugging his gun, armed with a belt of ammunition. The image took up a whole page and was titled 'Monzón trains to live'.'s One year before, El Gráfico, the best-selling and most prestigious magazine of its type within the sports market, had shown him aiming a shotgun at a poster of one of his rivals, the Italian Nino Benvenuti, whom he promised to 'kill' and 'let him have it from the beginning without pity' at their next fight. ${ }^{16}$

13 'It was outrageous', the manufacturer declared; 'sometimes human beings make mistakes. This is why one should be able to put right one's mistakes.' 'No al "guerrillero"', Gente, 563, 6 May 1976. Gente had devoted an article to the subject, which warned that 'the country is also being killed with a toy gun'. 'Un caso a favor: el fusil guerrillero no se fabrica más', Gente, 561, 22 April 1976, pp. 68-9.

14 Throughout the 1970s, Monzón was one of the most important and famous Argentine public figures. His image symbolised the 'macho' Argentine man, and he was presented in this way on various occasions. In 1973, for example, Gente magazine chose him as its 'superman of the year'. "73 iQué año! 365 días con la lupa de "Gente", Gente, 445, 3 I Jan. 1974.

is 'Monzón se entrena para vivir', Gente, 375, 28 Sep. 1972.

16 'Monzón y...', El Gráfico, 2658, 23 March 1971, p. 3 I. 
Figure i. Newspaper Spread, 'Las venganzas del Beto Alonso', I973

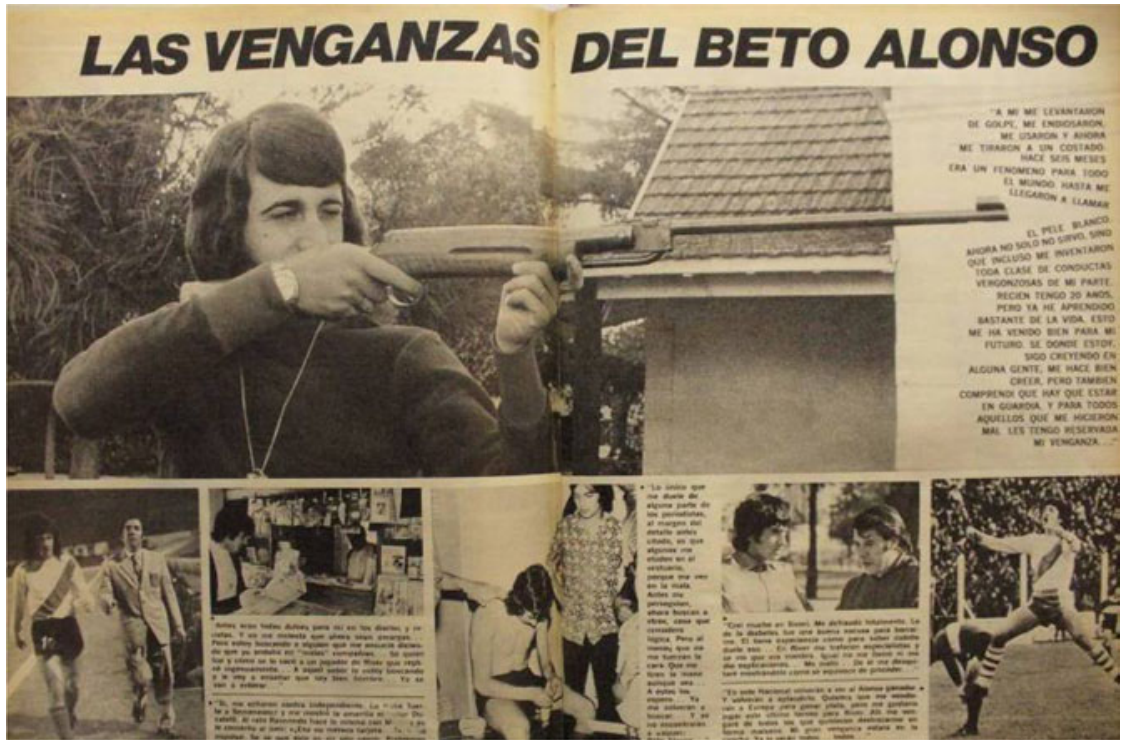

Source: El Gráfico, 281 5, i 8 Sep. 1973.

Violence is, of course, inherent to Monzón's sport. Presenting him posing with guns could have been merely a metaphoric juxtaposition of the power of fists and shotguns, the lethality of one and the other. However, similar articles were devoted to stars in other sports. In another issue of El Gráfico, 'el Beto' Alonso - star of the Club Atlético River Plate soccer team - swore revenge against those who criticised him as he posed for a photo that occupied much of the article's two main pages (Figure I). In the photo, he appeared with a gun in his hand, ready to shoot, with his eyes squinting as if taking precise aim at a target.

The naturalness with which great popular stars such as Monzón and Alonso promised violence with guns in hand, in mass media with a huge readership, is striking. It would be erroneous to conclude that this was solely related to the characteristics of these ads' protagonists or to the fact that they were athletes. Neither Monzón nor Alonso posed with weapons because they were violent men. Independent of how violent these individuals were, the presence of rifles and shotguns in these images and the advertisers' decision to present them to the public in this manner are indicators of a positive connotation that guns had at the time.

This can be confirmed when we direct our attention outside the sporting world, which always lends itself to relationships between rivals and enemies, opponents and fighters. The following examples come from the world of show business. In one case they feature two young models, and in the other, 
an acclaimed soap-opera actor. In an article for Gente, Marta Cerain and Horacio Bustos, a successful pair of models, told the publication about their lives and their desires, presenting themselves as an ideal couple: successful, hard-working, ambitious, beautiful and in love with one another. In the article, Cerain and Bustos declared that they wanted to be actors and have two children, at the same time claiming that they studied and worked more than I 4 hours a day. He said that he admired her simplicity and sweetness, and she, his strong personality and unique charm. The main photo that illustrated the story, titled 'A Beautiful Couple', showed them elegantly dressed, looking into each other's eyes. He was pointing a shotgun at her and she a revolver at him. ${ }^{17}$ Arnaldo André, an emblematic soap-opera leading man, appeared in a 1974 story in the same magazine where he expressed his desire to begin a more reflective chapter in his life. The story's main photo also showed him firing a shotgun. ${ }^{\mathrm{I}} 8$

In the I970s, hunting was an activity associated with a variety of positive values. Not only do magazine stories, such as the ones devoted to entertainment figures, corroborate this, but a long list of products also testifies to the notable sign of distinction - in a Bourdieuian sense - that this sport constituted. ${ }^{19}$ Jeans, shoes, pants, shirts, sports jackets, cigarettes, shaving creams, colognes and automobiles were among the products that were sold in association with the activity of hunting, always displaying guns in their advertisements. The art of handling weapons was associated with a set of socially positive values, such as friendship, status, masculinity and a lifestyle full of excitement, adventure and danger.

'Enjoy the season of friendship and live in Levi's', read one of the slogans of this jeans brand, among the most popular in the r970s. The image showed two young men, one with a beard and a beret and the other with a moustache and long hair, the latter with a rifle. The Shelton cigarette brand - one of whose slogans, 'for those in the know', denoted an elitism that was not so much economic as aristocratic, in the literal sense of the term - promoted its packs through an image of a select group of people in friendly conversation, smoking and holding guns. The words of the advertisement completed the image, affirming that its subjects 'could spend hours talking. They know the subject well. They understand guns. And cigarettes too.' ${ }^{20}$

That virility was associated with guns to promote products for men or boys is evidenced in a variety of advertisements. For example, Sorpasso, a brand of shoes, promoted one of its products displaying a pair of gloves, a shoe and

17 'Un matrimonio de gente linda', Gente, i 8 I, 9 Jan. I969.

${ }_{18}$ 'No... Ustedes no entienden. Yo estoy en otra cosa', Gente, 482, 17 Oct. 1974.

19 See Pierre Bourdieu, Distinction: A Social Critique of the Judgement of Taste (Cambridge, MA: Harvard University Press, 1984), esp. pp. 260-7.

${ }^{20}$ El Gráfico, 2583, 9 April 1969. 
a shotgun. The spare written message read: 'Masculine and unique'. ${ }^{21}$ Fittipaldi, a men's cologne, associated men and guns. Four men, all armed, surrounded a dead animal; 'It's a man thing', the slogan read. The weapons company Pasper promoted two of its products, the Robin Hood rifle and pistol, with images of the guns and a cartoon of the archetypal hero. 'Introduce your son to the manly sport of target shooting', the advertisement suggested. ${ }^{22}$

Most of the clothing brands that associated their products with guns instead emphasised the status assigned to those who used them. 'Finister is the shirt, the man is you', this men's clothing brand's slogan affirmed. A series of closeup images of the model showed the neckline, the back and the sleeve of the garment. A final image showed the subject in full for the first time, in a living room next to a log cabin. Next to the shirt, all of the images displayed, in part or in full, a gun. ${ }^{23}$ Cashmilon, a brand of sports jackets for 'people who have cash', advertised its products with two elegantly dressed men, wearing plaid sports jackets and carefully examining a shotgun. ${ }^{24}$

Other companies preferred to associate their products with guns for what the latter implied in terms of an exciting and adventurous lifestyle, highlighting attributes which, as we shall see, are characteristics of certain socially ascendant values such as dangerousness. The L\&M cigarette brand tended to show uppermiddle-class people in a jungle context with cigarettes in their mouths and weapons in their hands. ${ }^{25}$ Lord Cheseline, the well-known shaving cream brand, also featured guns prominently. 'Between us... I recommend a new instant emotion to you', read the ad's text; the accompanying image showed a man, with a steady, strong gaze and his face covered in shaving cream, holding a canister of Lord Cheseline in his right hand and a shotgun in his left. ${ }^{26}$

Hunting (as a sport or merely as a leisure activity), target practice and the taste for guns itself were without a doubt 'classing', in the sense that Bourdieu meant it. ${ }^{27}$ Associating a product with hunting or target practice was a widespread and probably successful marketing strategy. But there were also guns associated with products in contexts that had no relation to hunting. The Citroën Argentina Company, for example, attracted its clients through a fullpage notice that invited them to join the Ami 8 Club, where membership was associated with 'what people like you have'. The vehicle occupied a small part of the advertisement. The main image was of a collection of four pistols from the eighteenth century. The advertisement did not provide any more

${ }^{21}$ El Gráfico, 2901, 14 May 1975.

${ }^{22}$ Auto Club, 68, Jan.-Feb. 1973. Various advertisments urged children to demand a specific rifle or shotgun from their parents. The sports magazine Aire y Sol promoted one of its issues with a boy holding a rifle, ready to fire: see La Capital, 30 April 1973.

${ }^{23}$ El Gráfico, 2586, 29 April 1969.

${ }^{25}$ Gente, 328, 4 Nov. 1971.

${ }^{24}$ Panorama, 385, 19-25 Nov. 1974.

27 About this concept, see Bourdieu, Distinction, pp. 97-168. 
Figure 2. 'Mafalda' Cartoon

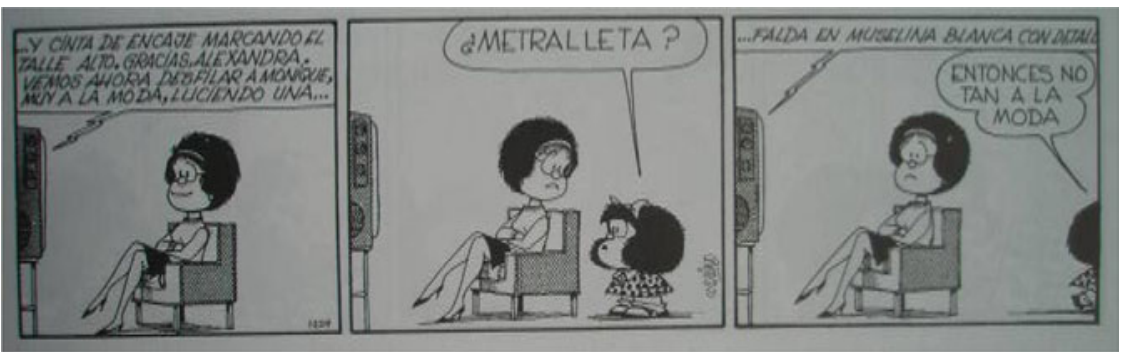

Source: Quino, Todo Mafalda (Buenos Aires: De la Flor, 1997).

information, beyond stating that the Ami 8 Club was a 'subtle result of the Citroën philosophy'. ${ }^{28}$

Guns were not exclusively associated with masculinity or products directed toward male consumers. In 1971 , the women's magazine Para Ti devoted an article to educating women about their rights within a civil marriage. The article was titled 'Down with Violence! Long Live Marriage!', and its main illustrations featured first two men with their hands behind their backs, as if they had been arrested, and then a lone man in the same position, with a woman pointing a shotgun at him. ${ }^{29}$ During the first half of the 1970s, both Para Ti and Claudia, another publication directed at a female audience, illustrated some of their extensive articles about suede garments, tricot fabric and practical designs for winter vacations with shotguns, revolvers and phrases extracted from violent rhetoric. ${ }^{30}$

Perhaps nothing better illustrates this association between fashion and guns than a comic strip featuring Mafalda, Quino's emblematic character, who was already very famous in the I970s and appeared in both high-circulation weeklies and newspapers. In the strip (Figure 2), Mafalda's mother is watching a fashion show on television. Walking past, Mafalda hears the programme presenter say: '... and a lace ribbon marking the high waist. Thank you, Alexandra. We'll now see Monique on the runway, very fashionable, showing off a...'. The little girl asks, 'machine gun?', and when she hears that she is mistaken - the model was wearing a 'white muslin skirt' - Mafalda leaves the room, muttering: 'Then she's not that with it.'

${ }^{28}$ Gente, 389, 4 Jan. 1973, p. 64; Claudia, 190, March 1973; Panorama, 297, 4-10 Jan. 1973, p. 49; Análisis-Confirmado, 518 or 396, 16-22 Jan. 1973.

29 '¡Abajo la violencia! ¡Viva el matrimonio!', Para Ti, 2539, 8 March i971, p. 65.

30 'Cuero: el asalto del año', Claudia, i 42, March ı 969, pp. 76-93; 'A la caza, a la pesca, y a la moda', Para Ti, 2555, June I971, pp. 48-5 I; 'Éxito 7 I: la gamuza', Claudia, 167, April 1971, pp. 154-7; 'Disparen sobre el tricot...', Claudia, 225, March 1976, pp. 53-9. 
Although far from comprehensive, this selection of advertisements serves to corroborate the positive connotation attributed to the use or mere presence of guns. Associated with activities that denoted status and social prestige, such as hunting or target practice, and used to assert ideas such as friendship, or to indicate an adventurous and risky lifestyle, guns flooded the symbolic space, accompanying many different products and people.

Their presence combined with the rise of certain values. In regard to women, different advertisements stressed the values of aggressiveness and of daring to live dangerously, the latter appropriating one of Mussolini's maxims. ${ }^{31}$ Leila, a women's underwear manufacturer, promoted one of its garments with the slogan 'Bold, aggressive, dare yourself!'; FlooCrem, a women's beauty products company, headlined its ads with 'Now! To look aggressively... feminine'; and the Miss Ylang company, which produced makeup and hair removal products, tempted its clientele through the concepts of '70 s woman... aggressively feminine' and 'Living dangerously'. ${ }^{32}$

If living dangerously and aggressiveness were now presented as feminine values, boldness, mercilessness and the search for power were those of the masculine world. Accompanied by a woman looking at the reader sensually and provocatively, one of the menswear brand Sportline's advertisements read: 'If a look like this makes you quiver (and you're also worried about the gas bill), then you're not fit to wear Sportline.' 33 Boldness, here, was opposed to hesitation, to those who let themselves be intimidated by others' glances, to those who think about the little things, the ordinary, the 'gas bill'. Doubt, indecision and fence-sitting were clearly viewed negatively. Even mercy was presented as a weakness - the clothing brand Modart, for example, emphasised in its ads that its clothing was for 'men that dress without compassion'. ${ }^{4}$

The positive value attributed to guns in the symbolic space raises questions about what exactly they represented. A gun is, in itself, a symbol of a drastic, final, irreversible action. Its use is linked to a radical, total and instant closure, which at the same time is a promise of an entirely new beginning, with the past erased entirely. Guns offer solutions of a magical character. The new world starts after the trigger is pulled. A shot, a bullet, signals both endings and beginnings. Guns are at odds with the ideas of patience, tolerance and moderation. Instead, they are perfect metaphors for urgency, intolerance and the extreme. Aggression, danger and mercilessness - in short, all the values that the advertisements extolled - were merely the temperamental leanings

${ }^{31}$ For an analysis of Mussolini's maxim 'vivere pericolosamente', see Christopher Duggan, A Concise History of Italy (Cambridge and New York: Cambridge University Press, 1994), chap. 8.

${ }^{32}$ See Para Ti, 2491, 6 April I 970 (Leila); Claudia, I46, July 1969 (FlooCrem); and Claudia, I 43, April 1969 (Miss Ylang).

33 Gente, 308, 17 June i 97 I, p. 50.

34 Gente, 408, 17 May 1973. 
displayed by those who shared the imaginary implicated in guns. It did not matter what access citizens actually had to guns. The question is how society must have been thinking in order for guns and the aforementioned values to constitute effective strategies within the symbolic space of advertising.

Guns were, in the early I970s, archetypal symbols of a series of beliefs, values and desires shared by a large portion of Argentine society. Solutions had to be immediate, things had to change radically, changes were only deemed effective if they were similar to shocks - and these views were totally independent of whether one was in favour of, or against, the guerrilla organisations or the military government, or closer to the Left or the Right. The I970s, more so than the decades that succeeded them, combined a cult around ruthlessness of action with a widely shared need or desire to institute irreversible change, from which no return would be possible. As a young sociology student affirmed on the cusp of the i970s: 'I think that we need to take the example of some adventurers. We have to be like Cortés: burn the boats, so that there is no return. The only way to commit oneself is with irreversible acts.' 35 This idea reflected a position held not only by activists; it was much broader and was probably shared by many social sectors. Whether they were close or far from the struggles of those days, activists and nonactivists tended to agree with some military leaders and the guerrilla groups on a belief founded on the rejection of gradual processes and a faith in extraordinary, almost magical actions that would split history in two like a bolt of lightning.

The positive values attributed to guns joined together the threads of these aspirations rather neatly. Roland Barthes has indicated that not only written discourse but also photography, cinema, journalism, sports, entertainment and advertising can all serve as a support for mythical speech. ${ }^{36}$ The mass media and especially the advertising business can then be studied as pillars of the mythical speech of a historical period. The characteristic of a myth, Barthes wrote, is to transform meaning into a form; to steal a signifying language and thereby naturalise a form. Thus, mythology is the study of ideas as forms. Following this approach, it is significant that the form to which guns refer can be expressed with the same words used in the survey cited at the beginning of this essay: 'clean slate', 'starting from scratch' and 'changing everything from the root'.

The mission of different political projects, at least from I 966 on, obeyed the same logic, regardless of their military or civilian nature and of the specific political project that each embodied. The nation had to die and be reborn: Onganía sought to 'revolutionise' it, Peronism sought to 'reconstruct' it,

35 'Crítico pájaro la juventud', Análisis, 458, 23-9 Dec. 1969, p. 44.

${ }^{36}$ Roland Barthes, 'Myth Today', in Mythologies (New York: Hill and Wang, 1972). 
and 'el Proceso' sought to 'reorganise' it. The syllable 're' in each case testifies to the intention to 'wipe the slate clean' and to enact the root-and-branch change judged to be necessary. In other words, this is the myth of radical closure as a necessary condition of another myth, a foundational myth, which presumes that history does not have its own history, but rather starts from zero after making a 'corpse' of the present that it aspires to abolish.

\section{Violence as Metaphor}

If many Argentine advertisements of the early I 970 alluded positively to guns, an even more significant number turned to metaphors of violence, with or without guns. References to bullets, shootings, explosions, abductions and kidnappings, added to metaphors such as having someone 'in your sights', aiming and opening fire, being ready to 'kill' or being armed (calzado), gave these advertising messages a unique tone.

On 29 May 1970, the Montoneros kidnapped and later killed former de facto president Aramburu. In July, some days after his corpse was discovered, the famous menswear company Modart, one of the most important companies in the country, announced discounts in the prices of its products, publishing an advertisement in newspapers and magazines that it had not previously used. It read: 'This is what it means to liquidate!' 37 Various clothing stores used this pun on the double meaning of 'liquidation', referring either to clearance of stock or to wiping out a person. The metaphor of kidnapping also began to be used often after the first abductions conducted by the guerrilla organisations.

The use of rifle scopes and circular targets was another common advertising trope. These could be found everywhere from magazine covers to advertisements for industrial bearings, in political ads for elections and in those satirising them. Panorama entitled its issue on the ambush of the C-Io Regiment of the Armoured Cavalry from the city of Azul by the Ejército Revolucionario del Pueblo (People's Revolutionary Army, ERP) in the province of Buenos Aires, 'Córdoba in the Sights'. ${ }^{8}$ The ambush angered Perón, and rumours deepened of a hardening of the executive branch with respect to factions that were least amenable to its plans, such as the state government of Governor Obregón Cano and his vice-governor Atilio López in Córdoba, both on the left of the Peronist Party. The political advertising for the Nueva Fuerza (New Force) liberal party, whose most dominant figure was the engineer Álvaro Alsogaray and whose presidential candidate in 1973 was Julio Chamizo, consisted of a poster with a drawing of a target, in which the 
Figure 3. Beverage Advertisment, 1969

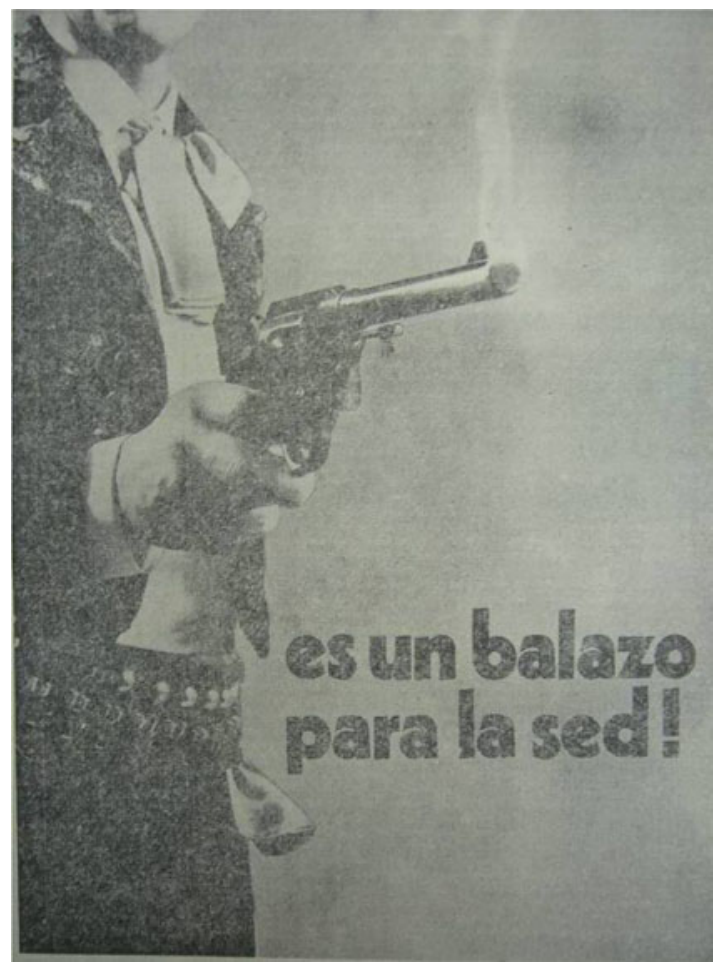

Source: La Capital, 5 Nov. 1969.

act of voting was compared to shooting at the bullseye. ${ }^{39}$ Satiricón magazine satirised this on its cover, with a drawing in which Alsogaray and Chamizo were featured naked in front of the target, fighting off arrows, eggs and knives being thrown at them, with bloodstains visible around the circumference of the target. ${ }^{40}$

The idea of an explosive discharge, whether a bullet (balazo), gunshot (tiro), cannon fire (cañonazo) or a bomb - was used in various advertisements, always connoting something desirable. 'It's a bullet for your thirst!' read a beverage slogan in 1969 (Figure 3). The ad was enigmatic not only because it did not show the face of its protagonist, but also because beyond a smoking revolver in his right hand, it did not offer any other information. Four days later, the same newspaper published a second ad that featured the slogan 'Defend your Talca', adding below, 'It's a bullet against your thirst. Take off your hats! ... Talca has arrived ... For your thirst. Fresh ... Refresh! Take aim with Talca ... the bold

39 Different versions of the New Force political party advertisements can be seen in El Gráfico, 2719, 16 Nov. 1971; and Para Ti, 2587, 7 Feb. 1972. $\quad 4^{\circ}$ Satiricón, 3, Jan. 1973. 
Figure 4. Slim Clothing Advertisment, I97o

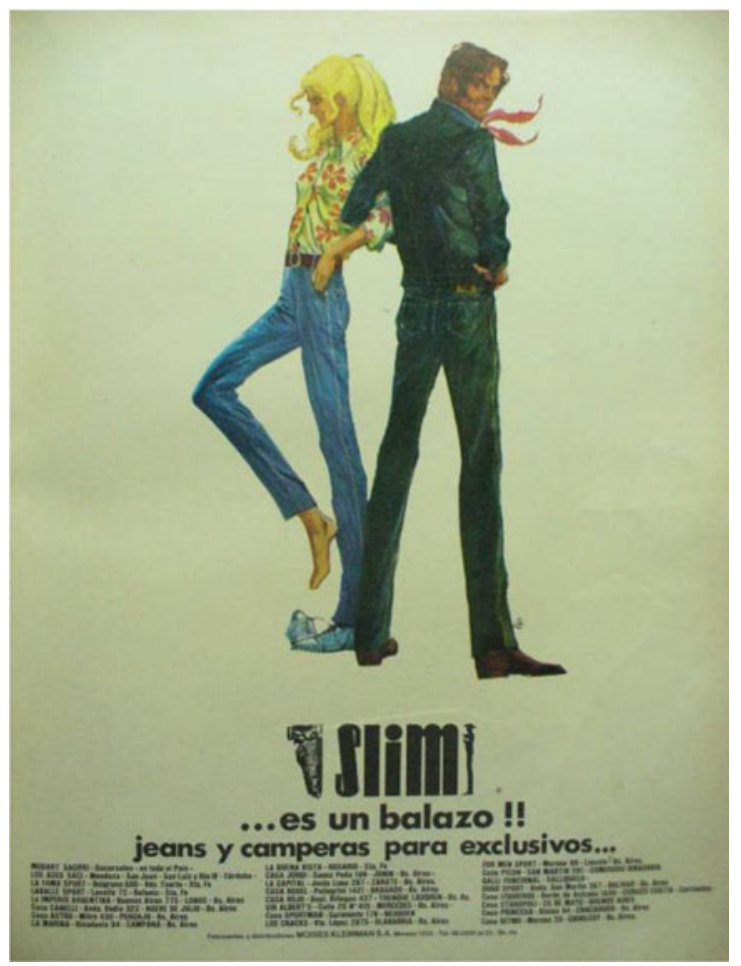

Source: El Gráfico, 2648, 7 July 1970.

flavour!' In this second advertisement, a woman drank the promoted beverage while leaning on the back of a Mexican cowboy as he took aim at the reader with a revolver in each hand. ${ }^{41}$

If Talca was a gunshot for one's thirst, Slim, an 'exclusive' brand of jeans and jackets, was a gunshot in clothing (Figure 4). Its slogan simply read: '...It's a gunshot!!'. And the digestive medicine Carqueja Trop was 'a gunshot' to normalise digestion; its ' 30 drops' were compared in an advertisement to ' 30 shots'. ${ }^{22}$ In 1974, Billiken magazine, from the Atlántida publishing house, widely read by school-age boys, advertised one of its issues with the slogan 'A Billiken that is a cannonball', alluding to the fact that the next issue would include a gift of a gun that shot 'harmless plastic projectiles', which was called the 'Billicañonazo'.43 A car dealership, Guerrero Automotores, used to publish ads relating its business to different metaphors involving weapons. In one of them, for example, the caption 'The bomb is at Guerrero', written over the 
Figure 5. Images from El Burgués, I972

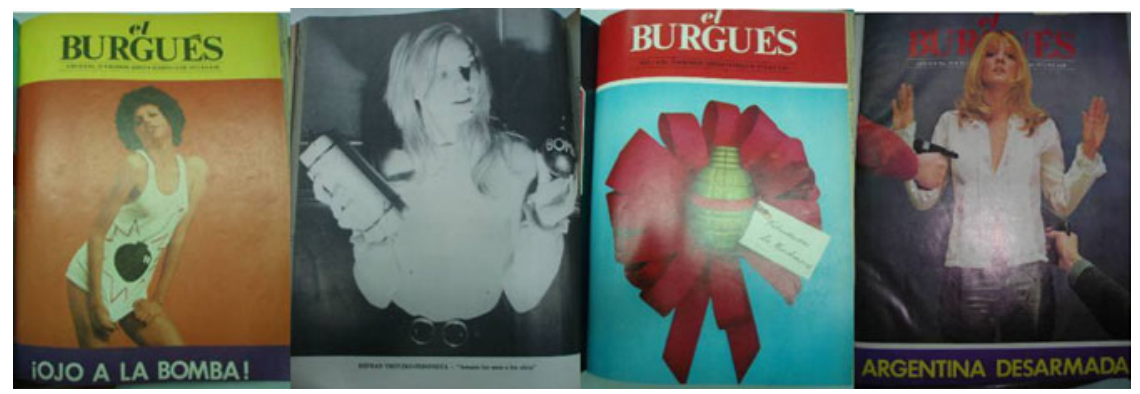

Sources: El Burgués, 16 Aug. 1972; 25 Oct. 1972; 5 Jan. 1972; and 7 June 1972.

image of a lit explosive, invited the customer to buy an automobile without fees and in interest-free instalments, so that he or she 'explodes with happiness'. ${ }^{44}$

It would be wrong to draw a direct relationship between the abundant presence of guns and metaphors for violence in the symbolic space and the political violence that characterised the first half of the decade. I argue instead that, beyond the concrete manifestations of violence and those groups or individuals that directly instigated such acts, these years unfolded against a background of an increasing subconscious acceptance of violence shared by broad sectors of Argentine society, a sort of pre-ideological second nature. It is significant, however, that a magazine noted the relationship mentioned above at the time. In November 1971, the magazine El Burgués, which was characterised by its high-quality full-page photographs, showed a draft for a cigarette advertisement in which the model, looking menacing, held a revolver in one of her hands. The next page showed Norma Arrostito, a member of the Montoneros armed organisation, walking and smiling. The photos were accompanied by a phrase that established a causal relationship between the two. 'When advertising raises this banner', the text under the model read, even 'the kindergarten teachers will become guerrillas', the magazine concluded under the photo of Arrostito.

Even more significant is that the same magazine that made this connection did not refrain from using references, often on its covers, to guns, grenades, bombs and so on, and that these references, while used to criticise the actions of the guerrillas, also contributed to the proliferation of the very violent metaphors and symbols that the same magazine questioned (Figure 5). The critique of violence thus resorted to using the symbols of violence.

Advertising did not shy away from ideas related to the armed political struggle and its ideological dimension. 'We are trying to prolong the war',

${ }^{44}$ La Capital, is Dec. 1969. 
declared the Banco Popular Argentino in an advertisement, referring to its claim that it offered better and more services, in a context where some Latin American guerrilla groups had proclaimed the slogan of a 'prolonged people's war'. ${ }^{45}$ The aviation company Austral, in a full-page advertisement, promoted its service through the headline 'Not with the left' and an image of an executive in a suit and hat. The ad's text indicated that the airline's flight attendants were 'young ladies that know what they are doing' and thus, when they serve the reader on a flight, although they might 'hold the tray with their left hand' - something that the ad deemed to be 'tolerable' - 'they will serve you with their right'. The humorous conclusion was: 'if at some point they serve you with their left hand, let us know. That means we've been infiltrated by a leftie $[z u r d a]^{\prime} .^{46}$ The advertising language of Argentina in the first half of the I970s is full of these types of light-hearted allusions to metaphors of violence. It constitutes an unequivocal record of the surprising naturalness with which the ideas of killing and dying, of war and subversion, of revenge and firearms, and even of infiltrators and informers were used in banal settings.

It was also in the early i970s that the verb 'to kill' became a positive superlative expression in Argentina, especially for young people, synonymous with something great or spectacular; to say that something 'killed' was to say that it surpassed all expectations. This expression displaced another that gradually fell into disuse: 'a kilo'. What was 'a kilo' in the I950s 'killed' in the I 970 . In a dictionary published by Gente listing the words used by the Argentine youth of 1975 , the expression 'killed a thousand' was defined as 'something sensational, that attracts attention, that causes surprise. Example: The girl put on some new jeans and killed a thousand.'47

Perhaps the most paradigmatic cultural artefact that embodies the spirit of the times was a television commercial from the Bonafide company, released in 1970 (Figure 6). The commercial was successful and, according to Héctor Solanas, president of Grant Publicidad, the agency that created it, 'emptied Bonafide's shelves'. ${ }^{8}$ The scene shows a highly sought-after actor of the period, Antonio Grimau, dressed in a suit, neatly groomed, sitting placidly at his desk, enjoying some of the company's candies. The camera angle is a closeup, focusing almost entirely on the actor's face and shoulders, so as not to give

45 Confirmado, 201, 24-30 April 1969.

46 Corsa, 227, 25-31 Aug. 1970.

47 'Informe "al día" para entender a los jóvenes de hoy', Gente, 535, 30 Oct. 1975, p. 68.

${ }^{4}$ Interview with Héctor Solanas, in Alonso Piñeiro, Breve historia de la publicidad argentina, p. 228. In the same interview, Solanas cited the Bonafide ad among his company's 'memorable campaigns' and defined advertising as 'part of the daily literature of a people'. It 'reflects what a people is and how they feel', especially in Argentina, where 'our way of being is full of spice. Our advertising is a little bit like we are, it's sharp, it's subtle.' Solanas, a clear embodiment of the conception of advertising that took shape toward the end of the 1960s, argued that 'one must understand, once and for all, that now we don't sell things, we sell states of being'. 
Figure 6. Still Images from Bonafide TV Commercial, 1970

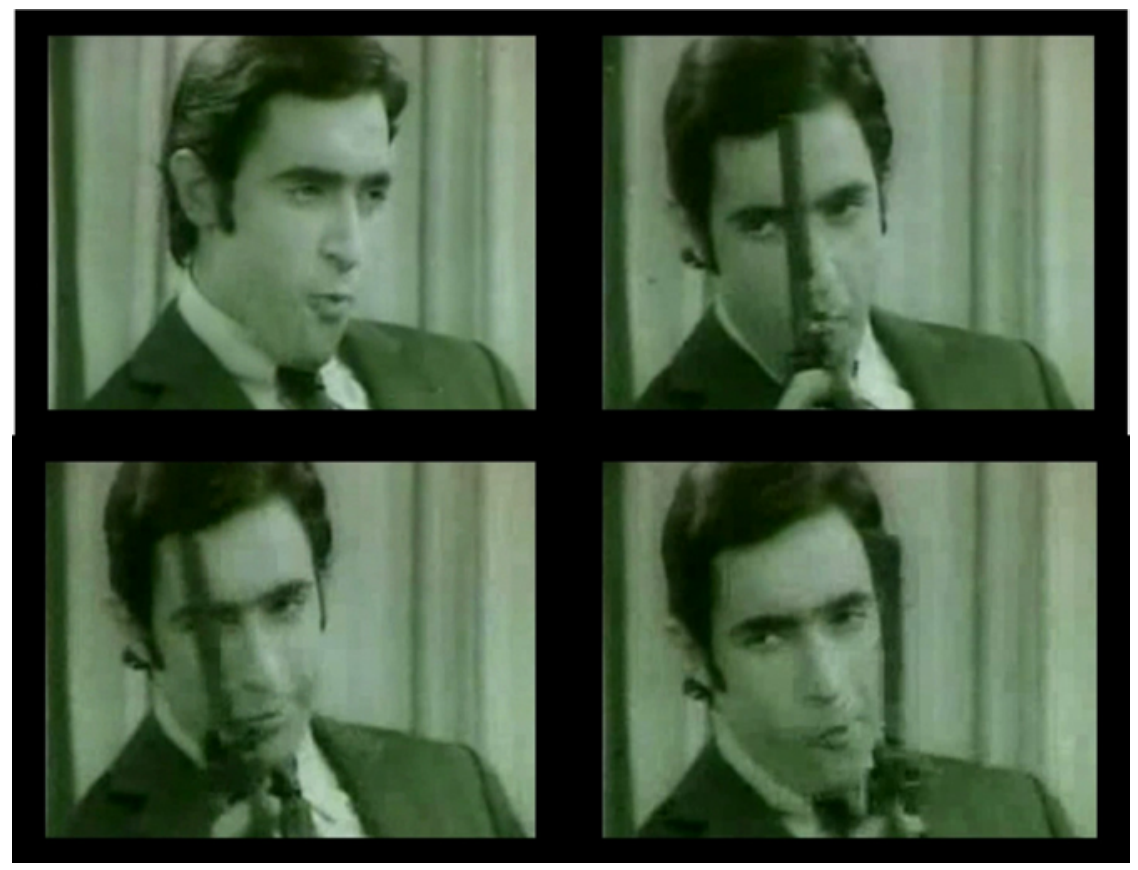

Source: see note 49 .

away what is happening in the rest of the scene. An off-camera voice asks: 'Excuse me, you're eating candy, right?' Grimau, who doesn't speak at any point in the commercial, responds affirmatively, nodding his head. 'And as far as I can see, they are the extra-fine candies from Bonafide', continues the speaker. Grimau responds that they are, once again with gestures. 'Yes, I know, those ones that are chocolate-covered; they must be delicious, right?' asks the speaker, and the actor continues nodding in response. When the off-camera speaker asks Grimau to give him one of the candies, the actor takes out a revolver and kills his interlocutor. ${ }^{49}$ 'Extra-fine Bonafide candies. For the selfish', the commercial concludes. ${ }^{\circ}$

49 This advertisement can be seen in the documentary COMA I3: del Cordobazo a Malvinas trece años de historia en imágenes, Part I (1969-74), available at www.veoh.com/watch/ v62365885 TGrnWgzE (last checked in July 201 4; advert begins at 24:50). In 1971, Bonafide announced the continuation of this spot. In the new version, Grimau once again eliminated the speaker who asked him for a candy, but this time he pressed a button that opened a trap door underneath his interlocutor, causing the latter to fall into an abyss.

so The Code of Ethics for Television Commercials, approved in 1968 by three associations connected to the industry, established that 'narration or staging of acts that imply a direct apologia for crime shall be avoided'. In I 970 , a commission composed of representatives of these associations objected to certain commercials and ordered their modification, in the 
The art of advertising tended and still tends to push the idea that a product is so delicious or so fabulous that those who possess it would do anything not to share it. In this sense, there is nothing surprising in Bonafide's ad. What is nothing short of amazing 40 years later, however - something that probably did not cause surprise in 1970 , as the thesis that I propose in this article suggests - is that a commercial strategy would include the staging of a murder in its promotion of a product, in a message conceived to attract an audience/ consumers.

I would like to advance two conclusions, one aesthetic and the other ethical. First, it seems clear that the representation of violence in the early i 970 s turned into an art form. This occurred not only in commercial art but also in art that presented itself as being politically 'committed' and circulated in more restricted environments. '[F]erocity will make us free', was the proclamation that a leftist artist attached to his work Project for a Monument to the Disappeared Political Prisoner, which called for art to 'liberate our colonised culture, opposing it with a counterculture of violence'.5 Between the end of the 1960 s and the middle of the 1970s, in tandem with the increasingly more technical and sophisticated exercise of what could be called the art of violence in the political world, the symbolic world was developing its counterpart representation: violence in art.

In reference to ethics in I970s Argentina, violence became a social bond, although this may seem paradoxical. In part this happened because, to the extent that violent practices multiplied and became commonplace, they began to be taken for granted in a very similar manner to that noted by Hannah Arendt in her essay On Violence. In other words, they became part of what everyone considered obvious, natural and, up to a certain point, unquestionable. ${ }^{22}$ The fact that violence played a large role in cultural consumption does not mean that consumers were more or less violent, however. It instead

majority of cases for 'attitudes or insinuations of a sexual nature'. Bonafide's ad, however, was not objected to. Instead, the commision affirmed that 'the film does indicate an intensification of subjects that include scenes of violence, and in accordance with the Ethical Norms for Television Commercials, we do not offer comments'. The commission, moreover, praised the wit, ingenuity, creativity and originality of the ad, as well as the actor's performance. See Appendix 3 of the Documentary Appendix, in Alonso Piñeiro, Breve historia de la publicidad argentina, pp. 278-84.

51 See 'Las obras de la revolución', Primera Plana, 496, I Aug. 1972, pp. 50-1. The full proclamation declared: 'Five propositions for Latin American art I) Make art into a tool to raise awareness of the present. 2) Liberate our colonised culture, opposing it to a counterculture of violence. 3) Find an opening toward the People as the only means of integrating art with reality. 4) Create from the borders inwards. 5) Love our own culture with the most ferocious of loyalties; hate the dominant cultures with the most implacable hatred. Because only ferocity will make us free.'

52 Hannah Arendt, On Violence (New York: Harcourt, Brace \& World, I969). 
indicates to what degree the community had incorporated violence into its habitus, as a curious form of sociability. ${ }^{53}$ Pierre Bourdieu called doxa the set of ideas, existing in all societies, that are assumed pre-reflexively, also defined as that community of values and beliefs prior to any deliberation that translate into an immediate adherence to what is evident. ${ }^{54}$ Social and mental structures overlap in the experience of the social world of the doxa. A particular historical order of relationships appears to be naturalised both in reality and in thought.

If killing a person on camera to sell candy was an act that a company was not afraid of being associated with, this is not because it wanted to appear linked with the idea of death, but rather because murder was an act that was socially trivialised, because violence had become banal. If we examine the concrete exercise of violence and the naturalness with which its promise and realisation were contemplated in s 970 s Argentina, the idea of the banalisation of violence can help us to think about that doxa, that background of tacit social acceptance of violence as an implicitly admissible method for resolving conflicts or disagreement, and even for relating to one another. 'Nobody examines or questions what is obvious for everyone', Arendt wrote of violence. ${ }^{55}$ The analysis conducted here shows the degree to which violence in I 970 S Argentina was simply 'there', was something obvious, was an unwritten rule. It formed part of everyday reality and its most convincing expressions came from radicalised social actors involved in the political struggle and from the state institutions charged with their repression. But it also made up a symbolic order that went beyond the particular political actors involved, and it is back to this order that the social fantasies which served as support to the behaviour of broad sectors of society can be traced.

\section{Violence as Fantasy}

During the first half of the I970s, images, metaphors and plays on words referring to violence were often used in Argentine advertisements that emphasised women's sensuality and seductive power. ${ }^{56}$ The use of seductive women in advertising was - and continues to be - a commonplace tactic. The change introduced in 1969 in Argentina was the combination of this tactic with guns and slogans that denoted violence or death. ${ }^{57}$ By contrast to those advertisements that included sporting or hunting firearms for shooting

53 Pierre Bourdieu, Practical Reason: On the Theory of Action (Cambridge: Polity, 1998).

${ }^{54}$ See Bourdieu, Distinction, p. 47 I. $\quad{ }_{55}$ Arendt, On Violence.

${ }^{56}$ Metaphors of seduction were also used to promote the sale of firearms, where the guns, not women, seduced. See 'Una línea en silueta', La Capital, i I Aug. I 972.

57 On the concepts of 'denotation' and 'connotation', see Roland Barthes, Elements of Semiology (New York: Hill and Wang, 1968), pp. 89-104. 
animals, the ads that combined sensuality and violence made use of revolvers or pistols, which can only be associated with violence against human beings.

In the advertisements analysed in this section, women who are either ready to use their weapons or have just done so appear in positions of domination or control of the situations that the ads represent. Although what these images depict does not belong to the political realm, the combination of danger, determination and desire that they connote inevitably echoed, in those years, the form that the Argentine political struggle was taking. In 1970, in a context in which the press was speaking of 'a wave of attacks', the police used the gender of the suspects to deduce whether common criminals or 'subversives' had conducted the attacks. ${ }^{5}$ If there were signs of female participation and the use of guns or explosives, they would conclude that it was the latter.

In reality, then, the 'women-and-guns' association was a political bellwether. In advertising, however, this translated into the language of consumption, cultural transformations and social fantasies. In the early i 970 , a motorcycle released by Gilera Argentina that was declared to be 'created for today's people' achieved some popularity. The advertisement that promoted it displayed the motorcycle in the foreground, while in the background stood a woman holding a revolver pointing straight ahead. The caption that accompanied the ad indicated that the SP 70 motorcycle was 'the only one with a licence to fire', adding in parenthesis, 'and how!'s9 'Please remember that I am made of wool ... and have pity: don't rinse me!' a sweater with its arms raised exclaimed in an advertisement for Wash Lan Oro, a cleaning product for wool fabrics. The scene was completed with a stylishly dressed and groomed woman who held a lit cigarette in one hand and a revolver pointing at the heart of the sweater in the other. ${ }^{60}$ Carqueja Trop, a digestive medicine, was advertised with the image of a woman blowing the smoke of her recently fired revolver to indicate to consumers that the product 'eliminates discomfort'. ${ }^{61}$

The advertisements featuring women holding guns are, on the one hand, a symptom of the questioning that had been going on since the 1960 s about traditional feminine gender roles both politically and, above all, culturally. Even in the ad where the woman appears performing a household task (washing clothing), both the cigarette she holds in one hand and the gun she grips in the other betray a feminine ideal that is different from the typical figure of the housewife. ${ }^{62}$ On the other hand, the combination of women and

${ }^{8}$ See 'La mujer argentina: jlibre o esclava?', Panorama, 176, 8-14 Sep. 1970, p. 25.

59 El Gráfico, 2617, 2 Dec. 1969, p. 73.

${ }_{60}$ Para Ti, 2436, i7 March 1969, p. 57 .

${ }^{61}$ La Capital, i 4 June 1971.

${ }^{62}$ For a view of women in this cultural transformation of gender relations at the time, see 'Víctimas, competidoras', Análisis, 472, 3 I March 1970. In this article, various women, including the young sociologist Silvia Sigal and the singer Marikena Monti, dialogue about 
guns shows that this ideal, this new position that woman began to occupy in Argentine society, ran parallel to a significant transformation of the values of that society. In line with the ascendant values mentioned in the previous section, the woman celebrated in these advertisements was one that had taken the bull by the horns. She went from being solely in the gaze of others to being someone who was still being looked at and desired, but was imposing the conditions under which that looking and that desire were channelled. Thus, the appearance of armed women in the symbolic space was a sign of shifts in the old gender role order, at the same time that it revealed a masculine universe threatened by women's willingness to assume values traditionally at odds with what supposedly corresponded to their nature.

In his research about the world of images and symbols of the members of the Freikorps - the volunteer armies that fought the revolutionary German working class between the end of the First World War and the rise of Nazism - Klaus Theweleit analysed the role played by the so-called Flintenweiber (literally, 'shotgun dames') of the Red Army in the symbolic imaginary of these German soldiers. ${ }^{63}$ The threat that the Flintenweiber presented for these men was not vaginal but rather phallic. Both fantasised about and feared, these women appeared as the bearers of symbolic penises (rifles) that represented, in the male mind, the threat of castration. Thus, Theweleit concludes that, for the Freikorps, armed women were more dangerous than armed men, because they symbolically possessed a terrifying sexual power that doubly threatened the soldiers, both on the real political-military level and on the symbolic level of virility and manliness.

In the Argentine advertising that I analyse here, however, the symbolic union between women and violence involved not only male fantasies but also fantasies that were shared by the entire society. If in the case of the Flintenweiber the fantasies associated with armed women were terrifying, in the case of Argentine advertising the images carried a greater ambiguity. Sensuality and violence in these advertisements had a connotation of both seduction and death. Guns strengthened the seductive character of the women just as women's beauty sweetened the guns' cruelty. In line with the rest of the examples considered in this article, desire and violence appeared as a pair, not only compatible with each other but also complementary. The violence of beauty was at the same time the beauty of violence.

On the other hand, death was alluded to doubly: literally in the images and the text that accompanied them, but also as a trope that included both

the new feminine roles in contrast to the traditional ones. The article is illustrative not only of the newness of this process but also of the limitations that characterised it.

${ }_{63}$ Klaus Theweleit, Male Fantasies (Minneapolis, MN: University of Minnesota Press, 1987), pp. 70-9. 
Figure 7. Paris Mediaslip Advertisments, I970

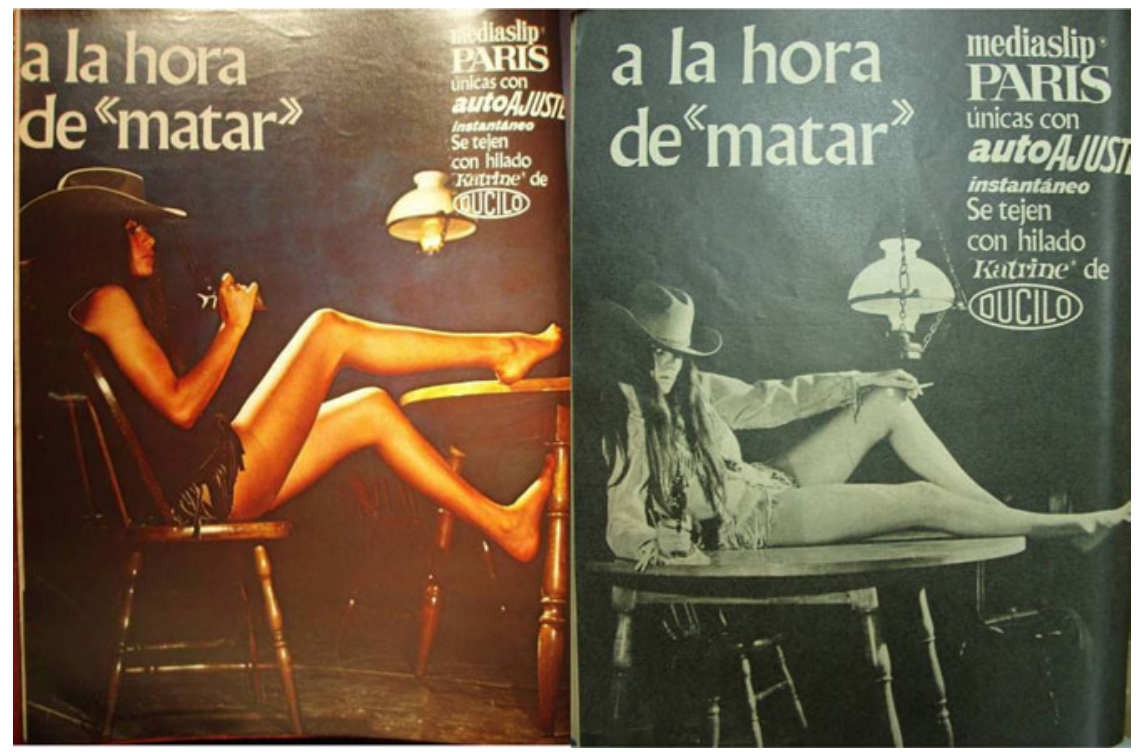

Sources: Para Ti, 249 1, 6 April 1970; Claudia, I 57, June 1970.

metaphor and metonymy, in the sexual nature of the desire involved. Sex and death, the desire for love and the desire for destruction, Eros and Thanatos, combined in a unique and unprecedented way - and the examination of this marriage allows for another reading that differs from and also completes that presented earlier.

In 1970, the Paris company advertised one of its products, the Mediaslip (pantyhose), with a set of advertisements whose slogan was 'When it's time to kill' (Figure 7). The ads featured a young woman in a dark room, sensually sitting on a chair or lying on a table, wearing only a vest, a hat and the product being promoted. In one of the ads she held a revolver pointing upward; in the other, the gun was pointed straight at the reader. The image immediately catches the eye: the sensuality of the model and her semi-nudity, combined with the word 'kill' and with the gun, obviously combine sex and violence. Sexual conquest is associated here with subjugation by arms. The fantasy that the guns imply is doubly present. From the perspective of women, represented by the model, it implies that to achieve a goal, one must be ready to kill. From men's perspective, with whose fantasies the ad deals, it implies that to attain what one desires, one must be ready to die. Furthermore, in both cases, both the killing and dying are presented as events that are not exceptional but are rather commonplace and ordinary, as natural as the use of the tights themselves. 
Something even more suggestive occurs in an advertisement for Tymsa, a brand of bra (Figure 8). From a wooden wall, which might be in a bar or other semi-public place, the presence of a fugitive woman is announced through the exclamation 'Wanted!' The image posted on the wall shows a young, attractive woman wearing a bra and a fur hat; she is blowing smoke from the end of a revolver, which she has apparently just fired. Below the model is written the slogan 'For killing in intimacy'. ${ }^{64}$

This ad, at the same time that it claims to search for the woman who has 'killed in intimacy', plays with the masculine fantasy of wanting to 'kill' (possess) a woman like the 'wanted' model. The phallic shape of the revolver an evident connotation when guns and women are combined, as Theweleit has indicated - is reinforced by the barrel's proximity to the model's mouth.

The meaning connoted in this case adds another element, absent in the Paris advertisements: the weapon has already been used, and the woman has already 'killed'. She has killed someone in an intimate situation and is enjoying the murder, sensually blowing the smoke from her recently fired gun. If the smoke symbolises the ejaculation, the image reflects less the sexual act itself (although it refers to it) than the post-coital moment. It is the moment after the orgasm, a moment of relaxation and serene enjoyment that follows the sexual pleasure itself. Consequently, killing was the orgasm, the climax alluded to by the image. Death itself appears as something to enjoy. The murdered victim is no longer in the scene; what is important is that he has dropped dead under the firepower and seductive power of the model. In this advertisement, the eroticism implied is very intense, and murder acquires the characteristics of orgasm.

Sex is linked with an archaic element, a primal impulse that precedes consciousness and that speaks from the base of the culture. It has the quality of presentifying not just any death, but rather that which results from a struggle, from a fight 'to the death' (as Hegel affirms in the master-slave dialectic), in which the desire has the objective of dominating the other and, in extremis, destroying the other. ${ }^{65}$ 'Born from Desire', wrote Alexandre Kojéve, 'the action tends to satisfy this desire, and can only do so by "negation", the destruction or at least the transformation of the desired object' ${ }^{66}$ In a strict sense, this philosophical tradition (Hegel-Kojève) understands desire as the struggle to annihilate the other, as the confrontation in which the subject searches for recognition through the subjugation and death of the other.

${ }^{64}$ Para Ti, 2675, is Oct. 1973.

${ }^{65}$ 'Presentify' is a Lacanian term meaning 'to make present' or 'bring up to date'.

${ }^{66}$ Alexandre Kojève, La dialéctica del amo y del esclavo en Hegel (Buenos Aires: Fausto, 1999), p. I 2 . 
Figure 8. Tymsa Advertisement, I973

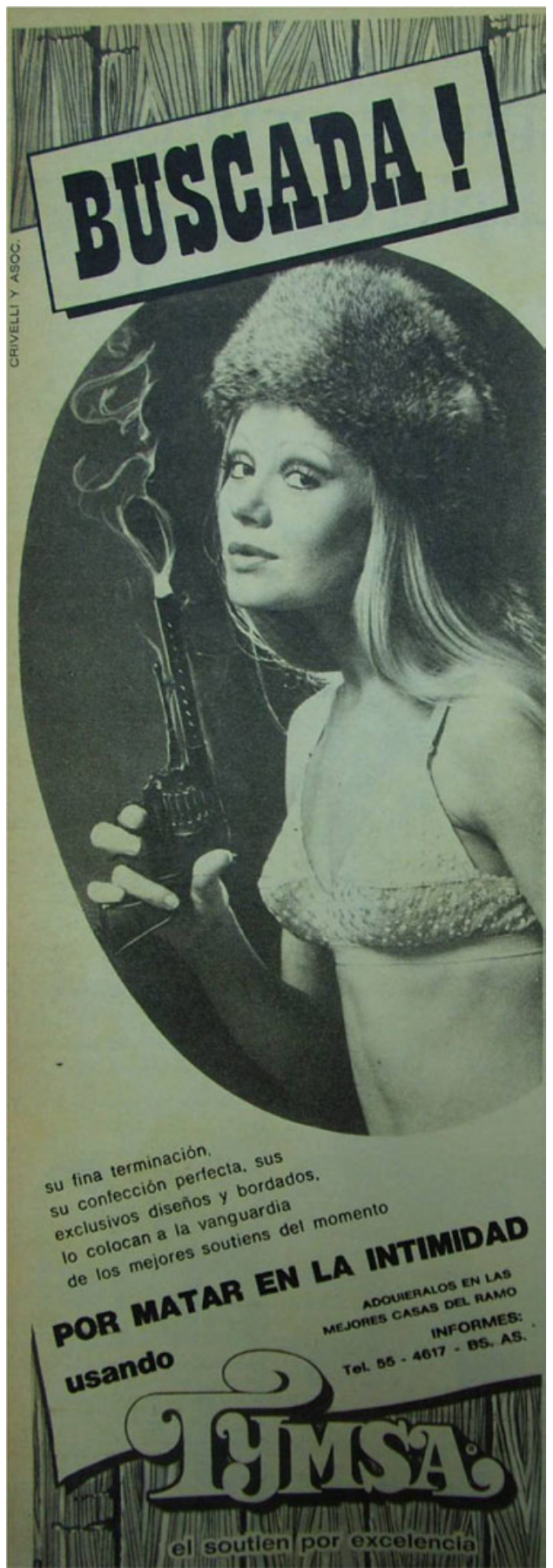

Source: Para Ti, 2675, is Oct. 1973. 
The fact that the images and slogans of the previously presented advertisements subject their appearance to the pleasure principle seems rather obvious. At the same time that they assure the woman who uses the advertised garments an unbeatable position on the terrain of seduction, they promise men the satisfaction of a fantasy, namely, that of feeling themselves at the whims of an overwhelming sensuality. The (men's) pleasure of desiring and the (women's) pleasure of feeling desired are present in a tangible way. But beyond this pleasure principle, on a more primal level, what this principle domesticates through its symbolisation is an elemental drive, the death drive.

These advertisements condense much of the symbolic world of early i 970 s Argentina because they allow us to see the point to which the death drive, always surreptitiously present, was explicitly manifested in the social imaginary, as if the inhibitory cultural mechanisms that favour social order were broken or became impotent. Violence and the eagerness for death appear eroticised in them. This is a phenomenon whose origins lie in a destructive drive, where sexuality plays a double role; that of Eros, insofar as it seduces and excites passion, but also that of Thanatos, as it empowers the metonymy that substitutes death for love (in place of 'when it's time to love', 'when it's time to kill'). In these images, sex and violence have the capacity of presentifying each other. Through guns and slogans, sexual desire presentifies death. Through the positions, clothing and attitudes of the models, violence presentifies sex. These advertisements have left an uneven record of their times, one in which love and death are confused to the point of explosion.

Focusing primarily on the case of the Montoneros, Hugo Vezzetti has called attention to the impact that the combination of 'politics, erotic drives and religion' had on violent revolutionary practices. ${ }^{67}$ These advertisements allow us to see the extent to which, regardless of political content and without referring to the actual struggles of those times, the erotic dimension of violence was present in the symbolic order of Argentine society. The death drive was a common ground. Politics was, without a doubt, the stage upon which it erupted with the most force, but we can better understand this phenomenon by examining the unusual form in which sensuality and aggressiveness, love and death, desire and violence were combined in the r 970 .

\section{Violence as Satire}

Just as violent metaphors sold products or promoted artists or athletes, print humour made society laugh by reflecting the violent form that politics had taken. Once again, it should not be inferred that those who made these cultural goods - in this case, humourists - legitimised violent acts. Instead,

${ }_{7}$ Vezzetti, Sobre la violencia revolucionaria, p. I 3 I. 
the fact that political violence became a cause for laughter, in many cases with great wit, is symptomatic of the way in which broad sectors of Argentine society conceived of the nature of politics, and also of violence. Political humour did not create conventions or social behaviours; instead, these found a channel of expression in humour.

Unlike the late I960s, when the humour dealing with violence focused on the international situation, ${ }^{68}$ in the early 1970 s domestic political violence became a frequent subject of vernacular humour. Caloi and Quino were two of the most famous Argentine humourists, who published their work in very popular magazines and newspapers. In a I970s cartoon entitled 'The Rules of the Game', Caloi depicted the situation within the Unión Obrera Metalúrgica (Metal Workers Union, UOM) through an image of a saloon in the western United States in which the union leaders, presented as Wild West cowboys, fought with one another. ${ }^{69}$ The drawing depicted a fight within the union that, a few days earlier, had ended with two deaths and several wounded at the metalworkers' union hall. Several months later, a meeting between members of the government and the general secretary of the Confederación General del Trabajo (General Confederation of Labour, CGT), José Ignacio Rucci, was depicted in another piece entitled 'Modus Vivendi'. Government and union representatives shook their right hands while hiding their left hands behind them, in which they carried sticks, a knife and an axe. $7^{\circ}$ The negotiations between unionists and businessmen in March $197 \mathrm{I}$ were portrayed by Caloi in a drawing in which the two parties sat face-to-face at different tables, each one of them with a bomb under the table. ${ }^{71}$ Thus, violence was depicted, as two of the cartoon titles suggest, as the given state of affairs, as part of the tacit rules of political life, as a naturalised way of living.

These jokes were situated in the political context of the ill-fated 'Argentine Revolution' that by $1970-\mathrm{I}$ was enjoying scant and decreasing sympathy. Two years later, in a different context (on I I March 1973, day of the elections that saw the Peronists emerge victorious), Argentine humour continued to reflect the strong climate of violence. A month before the inauguration of the new authorities, Quino described the political climate by conjugating the verb 'to love' with the six personal pronouns (I love, you love, he loves, and so on) in a cartoon. ${ }^{72}$ In each of the scenes, the characters appeared stealing a heart, always with larger and larger guns in hand. Loving and killing were combined. Less than a month after the new government had assumed power, Quino returned to this idea, drawing a person dressed in a suit writing a letter

${ }^{68}$ See, for example the 'Perro Mundo' comic strip from the humorist Heredia in the La Nación daily.

${ }^{69}$ Análisis, 464, 2-9 Feb. 1970, p. 4.

70 Análisis, 509, 15-21 Dec. 1970, p. $4 . \quad{ }^{71}$ Análisis, 521, 9-15 March 1971, p. 4.

${ }^{2}$ Panorama, 312, 19-25 April 1973. 
that he started with the salutation: 'Please accept the assurances of my highest esteem.' This character was shown with a revolver near his chest and guns and ammunition clips on his desk. ${ }^{73}$ Once again, although now referring to politics, love and murder appeared linked, with one being the counterpart of the other. The violence in these jokes allows us to see this widespread mode of thinking, surprising today but naturalised and a cause for laughter in the past, as one's chosen cause was asserted by means of arms. Probably, the cartoonist's intention was to underline the absurdity of declaring that one loves something, on the level of rhetoric, and then accompanying this affirmation with death in the material world. These drawings express a vision shared by part of Argentine society around 1973. On the one hand, the characters' violence and readiness to kill lets us glimpse the suspicion with which those who took up arms 'for love' were viewed. On the other, since violence and death threats were caricatured in a jocular manner, we can also see the extent to which this suspicion was translated into irony, much more so than indignation.

Alfredo Grondona White, Satiricón's cartoonist, caricatured a scene on the eve of the 1973 elections in which two young men, of a worryingly hippie 'look', walked around the city, with one saying to the other: 'Don't get angry!' [iNo te hagas mala sangre!] After the I Ith of March, everything will be alright.' Behind them were tanks, soldiers, protestors, a jail, a factory, a helicopter, explosions, some people fleeing, others dead, and two men leaning out of the windows of their cars firing machine guns. ${ }^{74}$

The same magazine published other drawings, jokes and texts that made reference to the reigning political violence of that year. Days before the elections and in advance of the 'winter wave of 1973', for example, the magazine joked that soon, Buenos Aires would have 'the best women's footwear for its elegance and durability (even after the cease-fire)'. This was the 'tank look' - pairs of armoured shoes with guns at their tips. ${ }^{75}$ Shortly before the assassination of union leader José Rucci by the Montoneros, Satiricón invented a table wine with his name, whose bottle's mouth had the shape of his face, satirising a well-known table wine that actually existed on the market, Crespi Seco. The ad read 'Rucci Seco. Guarded by experts', and depicted caricatures of three bodyguards, regularly associated with the union leader. The shadow of Rucci's head reflected at the bottom of the drawing had the shape of a revolver. ${ }^{76}$

Another talented humourist, Roberto Fontanarrosa of Rosario, also devoted some of his jokes to the political violence of the r970s. In one of these, for example, three men - who looked like hardened thugs wearing costumes from a party store - informed a blindfolded but smiling foreigner, to whom

${ }^{73}$ Panorama, 3 19, 7-13 June 1973. ${ }_{76}$ Satiricón, 6, 3 April i 973.
I5id. 
Figure 9. Fontanarrosa Cartoons, 1973-4

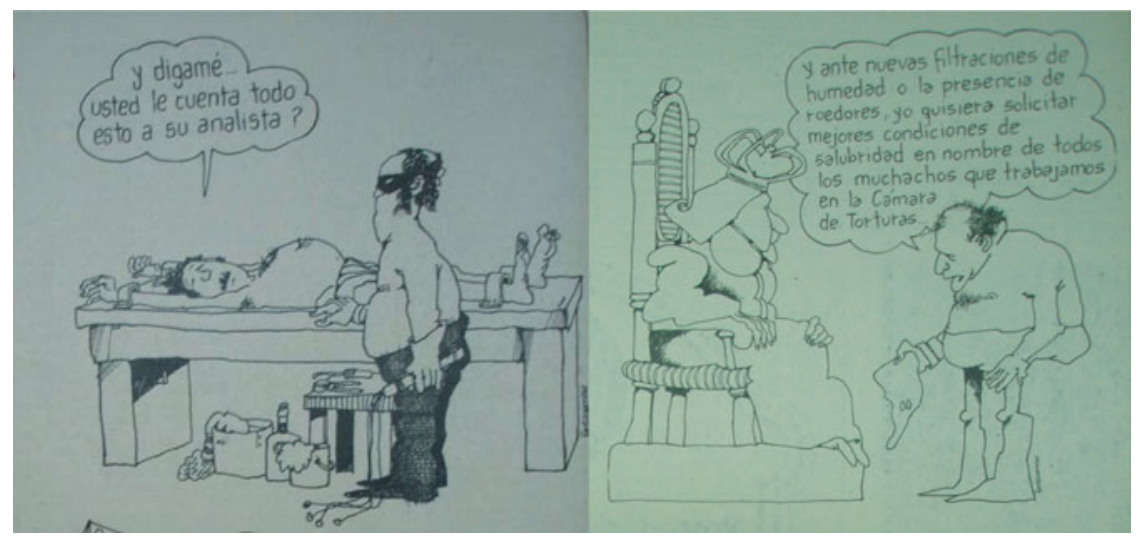

Sources: Panorama, 33 1, 20-6 Sep. 1973, p. 46; and 389, 17-23 Dec. 1974.

they referred as 'signore Ferrantelli', of three things: 'First, we are no longer at Patikindoulous' party. Second, we aren't playing blind man's bluff anymore. Third, we've just kidnapped you.' 77 Also in the early i 970s, Fontanarrosa drew a television reporter announcing the news of the kidnapping and murder of a big businessman. The joke was that the same journalist who was reporting the news was getting ready to kill him. ${ }^{78}$

Argentine humour did not ignore torture, which was not a new method in Argentina but was increasingly deployed as a repressive practice. The famous Mafalda, whose comic strip included various references to violence, upon passing by a street under construction where three men were working with a sledgehammer, drill and shovel to bore into the concrete, asked: 'What are they trying to get this poor street to confess?'79 In I 973, a democratic period, Fontanarrosa drew a torturer and his victim (Figure 9). Shackled to the torture table, facing his tormentor almost naked - the latter with his face partially covered and a cattle prod in hand - the victim asked the torturer: 'So tell me... Do you tell all this to your analyst?' The following year, the cartoonist returned to the same theme (Figure 9). This time the cartoon portrayed a queen - Isabel Perón, with her royal name, was already governing as president, following her husband's death in 1974 - whose subject respectfully was asking her: 'And due to new water leaks, damp and the presence of rodents, I wanted to ask you for better sanitary conditions in the name of all the boys who work in the Torture Chamber. ${ }^{80}$ In March 1974, the cultural criticism magazine

77 Panorama, 385, 19-25 Nov. 1974.

${ }^{78}$ Roberto Fontanarrosa, ¿Quién es Fontanarrosa? (Buenos Aires: De la Flor, I973).

79 Quino, Todo Mafalda, p. 250.

80 'The boys' (los muchachos) was a term associated with Peronist activists in political language. 
Crisis drew two priests speaking. 'They've told me, young man', said the older of the two, 'that you are rather severe in the confessional!', to which the young priest responded: 'Come on, come on, I just put a little voltage in the cattle prod!'8 ' Two years earlier, in his instruction manual for the 'jet set', Landrú suggested that those arrested for smuggling should testify before the judge or commissioner: 'Come on, judge. Will you let me go free if I give you the 200 cattle prods that I brought from the other side of the Iron Curtain?'82

In various periods of Argentina's history, political humour has been used as a tool to express what would be difficult to say in any other way. The common reading of this type of humour tends to value it for presenting a raw chronicle of reality, and sometimes for its commitment to criticising corrupt or immoral acts. The jokes connected to torture mentioned above could be an example. However, it is also true that both the humourists' audiences and the humourists themselves do not let themselves laugh about just any subject. It would not be very likely, for example, that some cartoonist today would craft a joke about the theft of children born in detention centres during the last dictatorship, nor would such a joke be published; moreover, neither the cartoonist nor their editor would be able to imagine an audience who would find this funny. What a society laughs about teaches us what is within the limits of the acceptable, the naturalised - what is converted into 'the rules of the game', as Caloi titled his excellent drawing, and what remains outside of those rules.

The banalisation of violence went to surprising extremes in I970s Argentina. On the night of 4 May I976, less than two months after the beginning of 'el Proceso', Alberto Olmedo, one of Argentina's most famous television and film comedians, staged his own disappearance. Upon introducing an episode of the El Chupete series, the announcer Jorge Nicolao reported with a serious air the 'unfortunate circumstance' of Olmedo's 'disappearance'. He did not say 'death', but 'disappearance'. ${ }^{3}$ Disappearance, even when the practice of disappearing people was occurring at the highest levels as an official policy, could be taken in jest.

The banalisation of violence in the long first half of the decade (1969-76) helps to explain how it was possible, when in 1976 state violence surpassed all predictions, that a society was willing to accept that hundreds of people were not in their homes and nobody knew anything about them. There was an

${ }^{81}$ Crisis, I I, March 1974.

82 Landrú, Gente paqueta (Buenos Aires: Orion, 1972), p. 65.

${ }^{83}$ See Carlos Ulanovsky, 1951-1976: Televisión Argentina, 25 años después (Buenos Aires: Hachette, 1976), p. 81; and ‘¿Muerto Olmedo se acabó la rabia?’, Cuestionario, June 1976, p. 6o. After this episode, the programme was pulled. Olmedo returned to television during the following year with his children's character, Capitán Piluso, and a year after that began Olmedo 78 . 
inevitable process of mimesis in the social sectors not involved in the political struggles, to which both the cultural products of the period and the actions and discourse of the key figures of political life testify. During the first half of the I970s, Argentine society systematically coexisted with news about torture, murder, execution, bombing, terrorism, and even kidnappings and disappearances. A unique social link was constructed based on the idea that violence was intrinsic to politics, and this notion, as has been noted, transcended the limits of politics. Violence was naturalised, and just as it was seeming to reach its end with the decision of the military to overthrow a government that many judged anarchic, it instead increased to unprecedented degrees. From a misrule that Arendt characterised not as 'a government of nobody' but rather as 'a tyranny without a tyrant', the society moved to Leviathan, a tyranny with a tyrant. ${ }^{84}$

In a perfect mirror of what was happening on the crudely material plane of reality, after the 1976 coup the symbols of violence became almost exclusively the monopoly of the state, which did not hesitate to exhibit them and promote itself as a Leviathan willing and able to monopolise all the violence possible and to exercise that violence whenever it judged necessary. The violent metaphors used to market goods or services from the private sector diminished and finally disappeared. Advertising showing the exercise or promise of violence rested exclusively in the hands of the state.

\section{Conclusions}

During the first half of the 1970s, violence exerted an attraction that was all but irresistible. If advertising incorporated guns and metaphors for violence into its language, this was less because it was imposing a habit on consumers and more because, on the contrary, it incorporated a social form into its art. In politics, violence was the distinctive sign. However, the excessive emphasis that researchers have placed on either justifying it ideologically or condemning it morally has generally come to overshadow the connection between political violence and this aggressive and authoritarian cultural background that was both its foundation and its stimulus.

In the I970s, violence and desire met and intertwined on a terrain that had been constituted for many years by different cultural traditions rooted in ideologies that were quite heterogeneous, although these were not unrelated to each other, such as male chauvinism, nationalism and militarism. Not being violent or not being ready or prone to act violently was a sign of weakness, of inauthenticity, of a lack of manliness in men or a lack of courage in women. 'We have reached the point', a journalist wrote in 1974 , 'that any appeal to peace seems to be melancholy moralizing, a cheesy sentimentalism of weak

${ }^{84}$ Arendt, On Violence, p. 72. 
spirits.' 85 From the point of view of the circulation of symbols, as Barthes wrote, contemporary culture in Western societies could be analysed in a way very similar to the analysis of smaller ethnic societies. Guns in advertising were, from a symbolic point of view, the phalluses of a society that measured its members based on how far one was willing to go, individually or collectively. Being willing to kill and die was the ultimate expression of bravery, and this aspiration brought with it prestige and honour. Not only the guerrilla organisations but activism and political involvement as a whole were some of the clearest expressions of this. ${ }^{86}$ In addition, violence in a general sense was incorporated as a form of being a macho (that is, not effeminate) man or a brave (and not cowardly) woman. The r 970 s in Argentina were characterised by abhorrence of all grey areas. The world that was coming, no matter what it might look like, did not seem to be for the indecisive or the hesitant; rather, it was for those who were ready to conceive of it in black and white, as all or nothing. In this sense, guns distilled what was associated with being healthy and full of life on the symbolic level: a glorious triumph or professional success, a romantic conquest or political victory. The violence of desire was also the desire for violence.

In an early work based on a study of an influential magazine, Carta Politica, Emilio de Ípola and Liliana de Riz postulated the existence of an 'Argentine ideology', whose stereotypes and beliefs were rooted in social consciousness to such a degree that they constituted a central part of the common sense of the majority of both political and social actors. ${ }^{87}$ For the authors, one of the two principal components of this ideology was the authoritarian political myth according to which it was the state's historical mission to construct the country it wanted 'from above'. ${ }^{88}$ 'The military officials of 1976 ', concluded de Ípola and de Riz in I 982, 'may have breathed a new vigour into this myth: but they cannot be accused of having invented it.' ${ }^{89}$ More recently, Beatriz Sarlo returned to the satisfaction that Aramburu's assassination produced in youth activist sectors, in order to try to understand it as 'a manifestation of a collective sensibility', one that was perhaps 'hegemonic on the radical fringes of Argentine politics'.90 The cultural texts analysed in this article, the majority of which were not directly related to the political sphere, allow us to extend the authoritarian component of the 'Argentine ideology' not just to the politics but also to the culture of the Argentine people, to expand the scope of this

85 'Para salir del infierno', Carta Politica, 7, winter 1974, p. 4.

${ }^{86}$ See, for example, the extra issue of El Descamisado that the Montoneros published after their event in the Atlanta stadium on I I March 1974.

${ }^{87}$ De Ípola and de Riz, 'Un juego de "cartas políticas", pp. 83-1 I 2.

${ }^{88}$ The other component referred to the myth of a country that was economically bountiful in riches and resources of every sort.

${ }^{89}$ Ibid., p. 105. $\quad 90$ Sarlo, La pasión y la excepción, p. 136. 
'collective sensibility' to sectors that were not politically radicalised, and to decouple both that ideology and that sensibility from specific events and historical characters.

In I 970 Argentina, death was thought of not as a problem but rather as a solution. The most outstanding aspects of the symbolic space predominant during almost the entire decade, at least from its beginning through the first three years of the dictatorship, can be seen as different inflections of the same metaphor, variations on the same myth. In 1973, Rodolfo Puiggrós, an intellectual with considerable influence within activist circles of the Left who was named rector of the Universidad de Buenos Aires under Peronism, declared that the academic appointments that he had made were 'positions in the struggle'. Contrary to what some of the 'men of ' 55 ' thought - that Peronism was a cancer that needed to be eradicated - 'it has already been demonstrated', Puiggrós said, 'that the Republic's health is in the Justicialist (Peronist) movement', that 'the cancer to be eradicated is on the other side of the street', and that 'we cannot be tolerant with those who conspire against the country, openly or secretly'. ${ }^{1}$ A short time thereafter, appealing to identical surgical metaphors and conspiracy theories not substantially different from those of Puiggrós, the state made a far deeper commitment to extermination and unleashed itself with unparalleled fury toward the end of the Peronist government and the dark first years of 'el Proceso'.92 The desire for violence, prefigured in Argentine popular culture, was now monopolised by a military regime that, far from metaphors and fantasies, converted death into a state policy.

\section{Spanish and Portuguese abstracts}

Spanish abstract. En Argentina, la década del setenta fue la más violenta del siglo XX. Su primera mitad estuvo caracterizada por el ascenso de la radicalización política, su segunda mitad por la brutal represión estatal. Los estudios dedicados a investigar la cuestión de la violencia en los años setenta se han concentrado fundamentalmente en sus protagonistas. Este artículo ofrece, en cambio, un análisis del terreno simbólico, llevando el análisis del plano consciente al inconsciente, del mundo real al imaginario. A partir del estudio de representaciones visuales en la cultura popular, especialmente de la publicidad en revistas de consumo masivo, este artículo indaga cómo la violencia fue naturalizándose durante la primera mitad de la década del setenta. Al hacer esto,

91 'Rodolfo Puiggrós: el nuevo peronismo en la universidad', Nuevo Confirmado, i 2-i 8 June 1973, p. 17.

92 See, for example, the declaration of the minister of foreign relations of the military dictatorship, César Augusto Guzzetti, in an interview with La Opinión, in which he affirms that 'the social body is contaminated by a sickness that is consuming its insides and is forming antibodies' and that, 'as the government controls and destroys the guerrillas, the antibody reaction will disappear', implicitly justifying what was then called 'the terrorism of the Right'. James Neilson, 'Murder Most Natural?', Buenos Aires Herald, I 2 Oct. 1976. 
suma un aspecto poco explorado a nuestro entendimiento del humor social que precedió el golpe militar de marzo de 1976.

Spanish keywords: Argentina, años setenta, violencia política, representaciones de la violencia, guerrilla y terrorismo de estado

Portuguese abstract. Na Argentina, os anos 1970 foram a década mais violenta de todo século XX. Na primeira metade, esta foi caracterizada pelo crescimento da radicalização política e, na segunda, pelo predomínio da repressão estatal. Estudos dedicados à investigação desta temática têm-se centrado fundamentalmente nos protagonistas. Por sua vez, este artigo oferece uma análise da esfera simbólica, em que o foco é alterado do plano consciente para o inconsciente e do mundo real para o imaginário. Ao olhar para representações visuais de violência na cultura popular, em particular as publicadas em revistas de alta tiragem, é explorada a forma como a violência se normalizou durante a primeira metade dos anos 1970. Deste modo, o presente artigo acrescenta uma nova camada à nossa compreensão sobre o clima social que precedeu o golpe de estado militar de Março de 1976.

Portuguese keywords: Argentina, anos I970, violência política, representações de violência, guerrilha e terrorismo de estado 